\title{
THE CHEMICAL AND MEDICINAL POTENTIALS OF THE FRUIT ESSENTIAL OIL OF Chrysophyllum cainito (INDIA STAR APPLE)
}

Ogunmola, O. O. Bolaji, O.S. \& Sodamade, A.

Department of Chemistry

\author{
Emmanuel Alayande College of Education \\ OYO, NIGERIA
}

\begin{abstract}
Chrysophyllum cainito is a lesser known fruit with several medicinal applications. The essential oil was obtained by hydrodistillation and was analysed by gas chromatographys/mass spectrometry, GC/GC-MS. Twenty components were identified in the essential oil, the oil was characterized by a high proportion of fatty acids (69.37\%) represented by pyruvic acid, 10-hendecenoic acid, E-9-tetradecenoic acid, pentadecanoic acid, hexadecacanoic acid and cis-9-octadecenoic acid. The oil yield was $0.19 \mathrm{v} / \mathrm{w}$ of the wet sample and its compositional profile showed markedly qualitative and quantitative variation with essential oil from Cuba. This essential oil was seen to be active against gram-positive bacteria, Escherichia coli, Klebsiella pneumoniae, Samonella typhimurium and Proteus mirabilis and also gram negative bacteria, Staphylococcus aureus and Streptococuss agalactiae.
\end{abstract}

KEYWORDS: Chrysophyllum cainito, essential oil, hydrodistillation, fatty acid

\section{RESUMO}

O óleo essencial do fruto de Chrysophyllum cainito foi obtido por hidrodestilação $e$ analisado com cromatografia gasosa e espectrometria de massa (GC-MS). Um total de vinte constituintes foram identificados no óleo essencial.que foi caracterizado pela presença alta de ácidos graxos (69.37\%). Os componentes principais foram os ácidos piruvico, 10-hexadecenoico, E-9-tetradecenóico, pentadecenóico, hexadecanóico e cis-9-octadecenóico. O rendimento foi 0.19 volume/peso da amostra molhada e o perfil composicional foi muito diferente do óleo essencial de Cuba tanto qualitativamente quanto quantitativamente. O óleo essencial mostrou atividade antimicróbica tanto contra bactéria gram- positiva com Escherichia coli, Klebsiella pneumoniae, Salmonella typhimurium e Proteus mirabilis qauanto gram-negativa como Staphylococcus aureus e Streptococcus agalactiae.

PALAVRAS CHAVE:Chrysophyllum cainito, Óleo essencial, Hidrodestilação, Ácidos graxos

E-Mail; ogunmolaoluranti@yahoo.com or layibolaii@gmail.com or

abbeyelectrochemical@hotmail.com 
Fruit Essential Oil of India Star Apple

\section{INTRODUCTION}

Traditional and folklore medicine plays an important role in health care services around the globe. Plants are known to synthesize a wide range of chemical substances, many of which have been and can be of tremendous value in treatment and prevention of diseases. Man has depended on the plants and plants extract as a source of medicine, food, shelter, clothing etc. since creation [15].

Herbal drugs have been one of the oldest practiced by mankind because of their cheap availability and wide application, scientist in various parts of the country concentrate on studies of these remedies in order to use these as an alternative to expensive imported drugs [12] several pharmaceutical companies are engaged in the development of natural product drugs through the isolation of the so-called active molecule from plant extracts. It is estimated that today, plant material are present in, or have provided the models for $50 \%$ western drugs [14].

Chrysophyllum cainito commonly called star apple belongs to the family sapotaceae, it usually comes in two forms, either the dark purple skinned variety with red-purple pulp or the green skinned variety with clear white pulp. In Nigeria, this fruit is not commonly eaten like the African star apple fruit, chrysophyllum albidum. This plant is a medicinal plant which contain substances that could be used for therapeutic purposes of which are precursors for the synthesis of useful drugs [1]. 
In Ivory Coast, decoction of the leaves is used for the treatment of hypertension, while in Cuba, a decoction of the leaves is used as a cancer remedy, while that of the bark is used as an antitussive (cough suppressant) [9]. In Eastern part of Africa, infusion of the leaves have been used against diabetes and articular rheumatism, while the bark is considered a tonic and stimulant. In Venezuela, the fruit and the seed are used as a diurectic and the ripe fruits because of their mucilaginous character are eaten to sooth inflammation, laryngitis and pneumonia. The latex of the tree in Brazil is applied on abscesses [7]. In Nigeria, few people eat the fruit because it is not common but those that eat it do so because of the sweetness and its mucilaginous character.

Chrysophyllum cainito belongs to the family sopotaceae and their chemical and biological studies are scarce [2] and there is lack of chemical information about the genus chrysophyllum, but a number of reports concerning the isolation and characterization of bioactive compounds from various parts of the plant have appeared in the literature.

The volatile constituents of star apple were extracted in Cuba [10], the essential oil were analyzed by GC-MS and one hundred and four compounds were identified in the aroma concentrate of which (E) -2-hexanal, limonene, linalool, copaene and hexadecanoic acid were found to be the major constituents.

In another study from Florida, fresh fruit of chrysophyllum cainito were extracted with methanol and partitioned with hexane and ethyl acetate sequentially. Nine known polyphenolic antioxidants were identified and epicatechin is present in highest concentration [6]. 


\section{SOUTHERN BRAZILIAN JOURNAL OF CHEMISTRY \\ SOUTH. BRAZ. J. CHEM., Vol. 23, No. 23, 2015}

Fruit Essential Oil of India Star Apple

The aqueous extract of the leaves was found at a dose of $20 \mathrm{~g} / \mathrm{l}$ to reduce the hyperglycemia of diabetic rat from $5 \mathrm{~g} / \mathrm{l}$ to $1.4 \mathrm{~g} / \mathrm{l}[5]$.

The extract of chrysophyllum cainito was used in goats against Haemonchos contostus[4] it was reported that the extract has nematocidal activity and this confirmed its use in ethnoveterinary practices and animal health management [11].

The purpose of the present investigation therefore was to extract, analyse and determine the antimicrobial activity of the essential oil of this lesser known fruit of chrysophyllum cainito.

\section{MATERIALS AND METHODS}

\section{Plant material and essential oil isolation}

Fresh fruits of chrysophyllum cainito (dark purple skinned variety) were collected from the campus of Ajayi Crowther University, Oyo in South West Nigeria in March, 2013. The sample was authenticated at the Forestry Research Institute of Nigeria (FRIN), Ibadan, where voucher specimens were deposited and was given voucher number FHI 109475. A sample of $700 \mathrm{~g}$ was pulverized using mortar and pestle. The fresh fruit was subjected to hydro-distillation method using an all glass Clevenger apparatus according to procedure described by European Pharmacopoeia [18]. The oil was collected and kept in refrigerator without further treatment until GC/GC-MS analysis. 
SOUTH. BRAZ. J. CHEM., Vol. 23, No. 23, 2015

O. O. Ogunmola, O.S. Bolaji and A. Sodamade

\section{Gas Chromatography/GC mass spectrometric analysis}

The chemical composition of the essential oil was analysed using GC-MS technique. The mass spectrometer was SHIMADZU GCMS-QP2010 plus (Shimadzu Corporation, Japan) in the electron impact (EI) ionization mode (70ev) and HP $5 \mathrm{MS}$ (bonded $0.25 \mu \mathrm{m}$ capillary column (restek, Bellefonte, PA) Injector and detector temperature was held at $60^{\circ} \mathrm{C}$ for 30 minutes then programmed to $240^{\circ} \mathrm{C}$ at rate of $5^{\circ} \mathrm{C} / \mathrm{min}$. Helium (99.99\%) was the carrier gas at a flow rate of $1 \mathrm{ml} / \mathrm{min}$. Diluted samples $(1 / 100$ in hexane $v / v)$ of $1.0 \mathrm{ml}$ were injected automatically, the linear velocity of the column was $36.8 \mathrm{~cm} / \mathrm{sec}$, each peak was then analysed and assigned a number in the order that it was detected. The identification of the components was based on comparison of their mass spectra with those of NIST library, mass spectra database and literature.

\section{Antimicrobial Activity Tests}

The antibacterial activities of the essential oil was measured against gramnegative (Escherichia coli, Klebsiella pneumoniae, Salmonella typhimurium and Proteus mirabelis and gram-positive Staphylococcus aureus and Streptococcus agalactiae using a well diffusion method according to the National Committee for Clinical Laboratory Standard [8]. Briefly, Petri plates containing approximately 25$30 \mathrm{ml}$ of nutrient agar medium were swabbed using cotton applicator with a 24 hours sub-cultured bacterial strains which were prepared in dilution to match the turbidity intensity of the MacFarland Standard. Wells (6mm diameter) were punched in the agar and filled with $10 \mu \mathrm{l}$ of the extracts of different concentrations $\left(1000,100\right.$ and $\left.10 \mu \mathrm{gml}^{-1}\right)$. The plates were incubated at $37^{\circ} \mathrm{C}$ for 24 hours. The antibacterial activities were assessed by measuring the inhibition zone diameter $(\mathrm{mm})$ around the well. 


\section{SOUTHERN BRAZILIAN JOURNAL OF CHEMISTRY}

SOUTH. BRAZ. J. CHEM., Vol. 23, No. 23, 2015

\section{Fruit Essential Oil of India Star Apple}

\section{RESULTS AND DISCUSSION}

Hydro distillation of the fresh fruit of chrysophyllum cainito produced a clear light essential oil. The oil yield is $0.19 \% \mathrm{v} / \mathrm{w}$ of the wet sample. The chemical components identified by GC/GC-MS are listed in Table 1. It was characterized by a high proportion of fatty acids $(69.37 \%)$ represented by $(\mathrm{IIz})-\mathrm{II}$ hexadecenoic acid $(24.42 \%)$, cis-9-octadecenoic acid (oleic acid) (13.04\%), E-9- Tetradecenoic (12.21\%), E-9-Hexadecanoic acid (9.54\%), Pentadecanoic acid (3.18\%), Nonanoic acid (pelargic acid) (3.18\%), Pyruvic acid (2.97\%) and 10-Hendecenoic acid (0.83\%).

The compositional profile of the fruit oil showed markedly qualitative and quantitative variation with that from Cuba. (E)-2-hexanal, limonene, linalool and copaene which are part of the major constituents of the oil from Cuba were not identified from the Nigerian oil sample, but hexadecanoic acid which was reported as one of the major constituents [10] is present in the Nigerian sample (9.54\%).

The oil is seen at different concentration to be active against gram-positive bacteria (Klebsiella pneumoniae, Salmonella typhimurium and Proteus mirabilis and also gram-negative bacteria Staphylococcus aureus and Streptococcus agalactiae as listed in Tables 2 and 3 and this can be compared with standard antibiotics as listed in Tables 4 and 5 . 
SOUTHERN BRAZILIAN JOURNAL OF CHEMISTRY

SOUTH. BRAZ. J. CHEM., Vol. 23, No. 23, 2015

O. O. Ogunmola, O. S. Bolaji and A. Sodamade

Table 1. Chemical Constituents of the fruit essential oil of chrysophyllum cainito

\begin{tabular}{|c|c|c|c|}
\hline$S / N$ & COMPONENT & $\mathbf{R I}$ & \% COMPOSITION \\
\hline 1 & 3-ethoxy-1-butane & 620 & 0.80 \\
\hline 2 & Divinyl sulfide & 650 & 2.97 \\
\hline 3 & 2,2-Dimethylpentanal & 821 & 0.80 \\
\hline 4 & 2-pentanethiol & 837 & 2.97 \\
\hline 5 & Heptan-3-one (ethylbutylketone) & 853 & 0.80 \\
\hline 6 & Tert-Butylcarbinol & 876 & 0.80 \\
\hline 7 & Pyruvic acid & 919 & 2.97 \\
\hline 8 & Monochloromethylisopentanoate & 946 & 0.80 \\
\hline 9 & Allyl pentanoate & 974 & 2.97 \\
\hline 10 & Methylcyclooctane & 1020 & 0.83 \\
\hline 11 & 2(3H)-Furanone & 1061 & 2.97 \\
\hline 12 & (4Z)-4-Methyl-4-undecene & 1199 & 0.83 \\
\hline 13 & Nonanoic acid (pelargic acid) & 1272 & 3.18 \\
\hline 14 & 10-Hendecenoic acid (Sevinon) & 1461 & 0.0 \\
\hline 15 & E-9-Tetradecenoic acid & 1777 & 12.21 \\
\hline 16 & Pentadecanoic acid (pentadecyclic acid) & 1869 & 3.18 \\
\hline 17 & Hexadecanoic acid (palmitic acid) & 1968 & 9.54 \\
\hline 18 & (11z)-11-Hexadecenoic acid & 1976 & 24.42 \\
\hline 19 & E-2-Octadecadecen-1-0I & 2061 & 12.21 \\
\hline 20 & Cis-9-octadecenoic acid (oleic acid) & 2175 & 13.04 \\
\hline \multirow[t]{2}{*}{21} & Methyl(13E)-13-docosenoate & 2483 & 0.83 \\
\hline & Total & & $99.95 \%$ \\
\hline
\end{tabular}


SOUTH. BRAZ. J. CHEM., Vol. 23, No. 23, 2015

Fruit Essential Oil of India Star Apple

Table 2.

Zones of inhibition $(\mathrm{mm}$ ) showing the antimicrobial activities of the essential oil at different concentrations (Gram-negative bacteria)

\begin{tabular}{|c|c|c|c|c|}
\hline Organism & $\begin{array}{l}\text { Escherichia } \\
\text { coli }\end{array}$ & $\begin{array}{l}\text { Klebsiella } \\
\text { pneumoniae }\end{array}$ & $\begin{array}{l}\text { Salmonella } \\
\text { typhimorium }\end{array}$ & $\begin{array}{l}\text { Proteus } \\
\text { mirabilis }\end{array}$ \\
\hline Conc $\left(\mu g m l^{-1}\right)$ & 100010010 & 100010010 & 100010010 & 100010010 \\
\hline $\begin{array}{l}\text { Zone of } \\
\text { inhibition }\end{array}$ & $\begin{array}{lll}15 & 08 & 09\end{array}$ & $\begin{array}{lll}13 & 13 & 13\end{array}$ & $\begin{array}{lll}12 & 12 & 12\end{array}$ & 1313 \\
\hline
\end{tabular}

Keynote $=$ no inhibition, $6-9 \mathrm{~mm}=$ low inhibition $10-15 \mathrm{~mm}=$ moderate inhibition $\geq 15 \mathrm{~mm}=$ high inhibition.

Table 3.

Zones of inhibition $(\mathrm{mm}$ ) showing the antimicrobial activities of the essential oil at different concentrations(Gram-positive bacteria).

\begin{tabular}{|l|lcc|lcc|}
\hline Organism & \multicolumn{3}{|l|}{ Staphyococcus aureus } & \multicolumn{3}{|c|}{ Streptococcus agalatiae } \\
\hline Conc $\left(\mu \mathrm{gml}^{-1}\right)$ & 1000 & 100 & 10 & 1000 & 100 & 10 \\
\hline Zone of inhibition & 17 & 13 & 13 & 15 & 15 & 15 \\
\hline
\end{tabular}

Keynote $-=$ no inhibition, $6-9 \mathrm{~mm}=$ low inhibition $10-15 \mathrm{~mm}=$ moderate inhibition $\geq 15 \mathrm{~mm}=$ high inhibition. 
O. O. Ogunmola, O. S. Bolaji and A. Sodamade

\section{Table 4.}

Zones of inhibition $(\mathrm{mm}$ ) showing the antimicrobial activity of antibiotics (Gram -negative bacteria)

\begin{tabular}{|l|l|l|l|l|}
\hline \multicolumn{1}{|c|}{$\begin{array}{c}\text { Antibiotics/ } \\
\text { concentrations }\end{array}$} & $\begin{array}{l}\text { Escherichia } \\
\text { coli }\end{array}$ & $\begin{array}{l}\text { Klebsiella } \\
\text { pneumoniae }\end{array}$ & $\begin{array}{l}\text { Salmonella } \\
\text { typhimorium }\end{array}$ & $\begin{array}{l}\text { Proteus } \\
\text { mirabilis }\end{array}$ \\
\hline $\begin{array}{l}\text { Nitrofurantoin } \\
(200 \mu \mathrm{g})\end{array}$ & 25 & 20 & 15 & 15 \\
\hline $\begin{array}{l}\text { Ofloxacin } \\
(5 \mu \mathrm{g})\end{array}$ & 20 & 20 & 22 & 33 \\
\hline Gentamicin $(10 \mu \mathrm{g})$ & 24 & 15 & 18 & 16 \\
\hline
\end{tabular}

Keynote $-=$ no inhibition, $6-9 \mathrm{~mm}=$ low inhibition $10-15 \mathrm{~mm}=$ moderate inhibition $\geq 15 \mathrm{~mm}=$ high inhibition.

\section{Table 5.}

Zones of inhibition $(\mathrm{mm})$ showing the antimicrobial activities of antibiotics (Gram -positive bacteria)

\begin{tabular}{|l|l|l|}
\hline \multicolumn{1}{|c|}{$\begin{array}{c}\text { Antibiotics/ } \\
\text { Concentrations }\end{array}$} & $\begin{array}{l}\text { Staphylococcus } \\
\text { Aureus }\end{array}$ & $\begin{array}{l}\text { Streptococous } \\
\text { agalactiae }\end{array}$ \\
\hline Nitrofurantoin $(200 \mu \mathrm{g})$ & 28 & 11 \\
\hline Ofloxacin $(5 \mu \mathrm{g})$ & 20 & - \\
\hline Gentamicin $(10 \mu \mathrm{g})$ & - & - \\
\hline
\end{tabular}

Keynote $=$ no inhibition, $6-9 \mathrm{~mm}=$ low inhibition $10-15 \mathrm{~mm}=$ moderate inhibition $\geq 15 \mathrm{~mm}=$ high inhibition . 


\section{SOUTH. BRAZ. J. CHEM., Vol. 23, No. 23, 2015}

\section{Fruit Essential Oil of India Star Apple}

\section{CONCLUSION}

The results obtained in this study showed that the fruit essential oil of chrysophyllum cainito from South West Nigeria has a qualitative and quantitative variation from the one obtained in Cuba and this can be traced to the tropical nature of Nigeria. This study is the first in Nigeria, to the best of my knowledge.

\section{REFERENCES}

1. O.A. Abolaji,A.H.Adebayo and O.S.Odesanmi, (2007). Nutritional qualities of three medicinal plant part (xylopia aetheopica, bligha sapida and parinar polyandra) commonly used by pregnant women in Western part of Nigeria. Pakistan Journal of Nutrition 6:665-668

2. V.C. Dasilva, M.N.Lopes and V.S. Bolzani (2006). Chemical study of leaves of chrysophyllum margination Nova 20:3 retrieved online from http://dx:dol.org/10.1590150100-40422 on 07-11-2014.

3. European Pharmacopoeia (2008). retrieved fromhttps://www.edqm.eu. on 08-11-2014

4. J.B.Githiori, S. Athanasiadou and S.M. Thamsborg (2006). use of plant in novel approaches for control of gastrointestinal helminthes in livestock with emphasis on small ruminants Veterinary Parasitology 139:308-320

5. N. Koffi,A.K. Ernest, Marie-Solange,K. Beogreand Z.G. Noel (2009). Effect of aqueous extract of chrysophyllum cainito leaves on the glycemia of diabetic rabbits. African Journal of Pharmacy and Pharmacology. 3 (10): 500-506 
SOUTHERN BRAZILIAN JOURNAL OF CHEMISTRY

SOUTH. BRAZ. J. CHEM., Vol. 23, No. 23, 2015

O. O. Ogunmola, O. S. Bolaji and A. Sodamade

6. Luo, X., Basile, M.J. and Kennelly, E.J. (2002). Polyphenolic antioxidant from the fruits of chrysophyllum cainito L. (star apple). Journal of Agric Food Chemistry 50 (6): 1379-1382

7. J. Morton, (1987). Star Apple in fruits of Warm Climates, Julica F. Miams Morton. 408

8. National committee for clinical laboratory standards (1993).

Retrievedonline from www.nchi.n/m.nih.gov/pmc.on 17-07-14

9. National Research Council (2008). "Star apples". Retrieved from http://books. Napedu/openph on 17-07-2014.

10. J. Pino, R. Marbot and A. Rosado (2002). Volatile constituents of star apple chrysophyllum cainito $L$ from Cuba. Flavour and Fragrance Journal. 17 (5): $401-403$

11. S. Rochfort, A. J. Parker and F.B. Dunshea (2008). Plant bioactivities for ruminant health and productivity. Phytochemistry, 69, 299-322. Retrievedonlineatwww.elsevier.com/locate/photochem.

12. A.Sofowora (1993).Medicinal Plant and Traditional Medicines in Africa, Chichester John wiley and Sons, New York. 20-23.

13. T.A. Tor-Anyiin, R. Sha'ato and H. O. A. Oluma (2006). Phytochemical screening and antibacterial activity of cissampelos mucronata. A rich menispermaceae extract. Journal of Pharmacy and Bioresources 3(2):103-106

14. F. Venter and J.A. Venter (1996).Making the most of indigenous trees, Briza Publications, Pretoria. 260-263

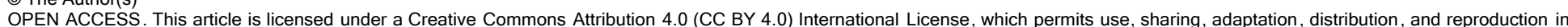

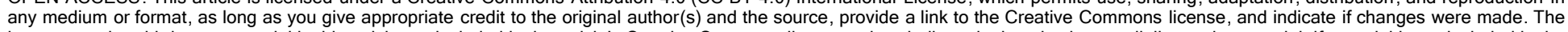

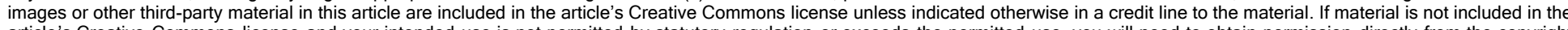

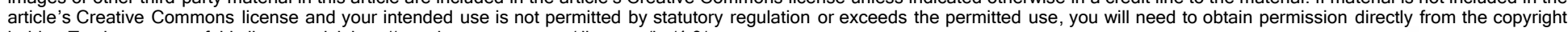
holder. To view a copy of this license, visit http://creativecommons.org/ licenses/by/4.0/. 